\section{Which compression for mild to moderate C3 patients?}

\author{
Didier Rastel, ${ }^{1}$ Nassima Fellah, ${ }^{2}$ \\ Bertrand Lun ${ }^{1}$
}

${ }^{1}$ SCOTT, non-profit association, Grenoble, France; ${ }^{2}$ Hospital of Blida, Algeria

\section{Introduction}

Lower limb edema is a complication of patients suffering from superficial chronic venous disorders (SCVD). Classified as stage $\mathrm{C} 3$ of the CEAP classification it is defined as a perceptible increase in the volume of fluid in skin and subcutaneous tissue, characteristically indented by pressure. ${ }^{1}$ In spite of this clear cut definition, the incidence of this stage varies from $2.2 \%$ to $13.4 \%$ in recent epidemiological studies that used CEAP classification..$^{2-4}$ This has been confirmed by CEAP interobserver variability with the least agreement obtained for class C3.,6 Recently it has been shown that the routine use of ultrasounds can detect, early in the day, patients with negative pitting test and who have edema in the deep layers of the skin. ${ }^{7,8}$ They are defined as mild to moderate $\mathrm{C} 3$ patients and to treat them, adapted levels of pressure, elevated enough to reach hypodermis, are required.

In order to precise which compression, mild, moderate or strong, can be the most appropriate to these patients, we carried out, in routine, measurements of the dermal thickness of mild to moderate $\mathrm{C} 3$ patients compared to patients without edema.

\section{Materials and Methods}

It was a prospective monocentric study involving a $15 \mathrm{MHz}$ ESAOTE probe in B mode; the first investigator performed images capture at the medial part of the ankle from 10 to $20 \mathrm{~cm}$ above the inner malleolar tip of patients who attended the phlebological clinic and to whom ultrasound investigations were routinely performed.

Two series of images were collected: 50 images with edema from patients with superficial venous disorders, $\mathrm{C} 3 \mathrm{~s}$ to $\mathrm{C} 4 \mathrm{a}$ EpAsPr, and 50 images from patient without edema.

To avoid possible biases, were included only patients less than 80 year-old and only if they had had the ultra sound image acquisition not later than 6 hours after waking up. Then the images were blindly send to a second investigator for the dermal off-line evaluation (Figure 1). The dermal thickness was defined according to a previous work and measured using the same ESAOTE MyLab software. . $^{7}$ Student's $t$-test was used for results comparison.

\section{Results}

The patients were $65 \pm 13$ year-old and $53 \%$ were female. The two groups, edema (OG) versus no edema (NOG), were comparable for age $(\mathrm{P}=0.18)$, but not for body mass index, which was higher, 28.4 \pm 5.6 , in the $\mathrm{OG}$ and $(\mathrm{P}=0.0013)$. The dermal thickness was higher in the OG $(1.39 \pm 0.34 \mathrm{~mm}$ vs $1.22 \pm 0.2 \mathrm{~mm}: \mathrm{P}=0.004)$ but no significant difference was observed between mild and moderate $v s$ important edema $(1.43 \pm 0.40 \mathrm{~mm}$ vs $1.33 \pm 0.22 \mathrm{~mm}: \mathrm{P}=0.38)$ when a qualitative 3 stages grading was used (Figure 2).

\section{Discussion and Conclusions}

From ancient and recent data, patients suffering from superficial venous disorders with negative pitting test can be affected by edema if detected early in the morning by ultra-sounds. ${ }^{7-9}$ This can explain the different results of edema frequency in the epidemiological studies. Consequently these patients with mild to moderate edema should be considered as patients with a complicated chronic venous disease and be treated by compression.

The main here presented results demonstrated that edema in mild to moderate C3 patients is not only localized into the deep layers of the sub-cutaneous tissues but also in the dermal layers. As a consequence, compression should be active though a massaging effect at the dermal level likely using a mild compression and at a deeper level with a stronger compression in order to drain from the distal part of the leg to proximal.

Subsequently, for a better strategy of treatment a mild compression would be more effective for a massaging effect at the dermal level while a stronger compression, targeting the deeper layers, would be more appropriate to drain fluid from distal to proximal part of the leg.

Should it be done using the same device or should it use a strategy with two different devices applied at different time of the day, it is still a pending question?
Correspondence: Didier Rastel, SCOTT, nonprofit association, Grenoble, France.

E-mail: d.rastel@wanadoo.fr

Conference presentation: International Compression Club (ICC) Meeting, Rotterdam, 2018.

This work is licensed under a Creative Commons Attribution 4.0 License (by-nc 4.0).

CC Copyright D. Rastel et al., 2018

Licensee PAGEPress, Italy

Veins and Lymphatics 2018; 7:7983

doi:10.4081/vl.2018.7983

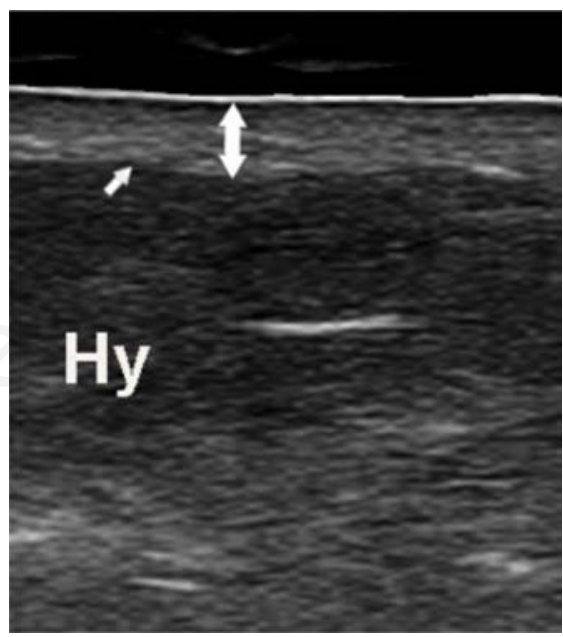

Figure 1. $15 \mathrm{MHz}$ ESAOTE probe $\mathrm{B}$ mode image of the skin at the ankle level. Dermal thickness (double white arrow); dermohypodermis limit (single white arrow); hypodermis ( $\mathrm{Hy})$.

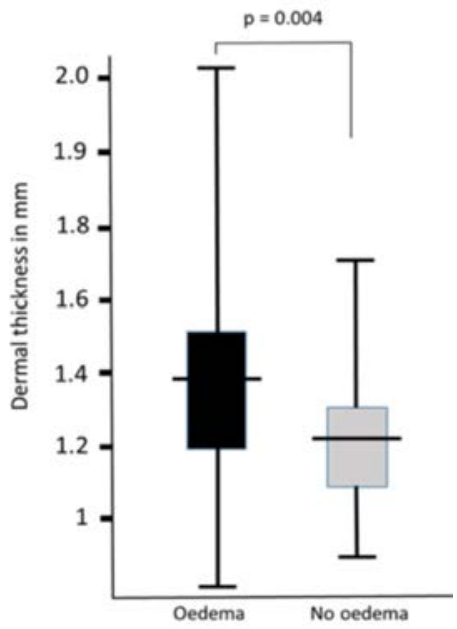

Figure 2. Comparison of dermal thickness in $\mathrm{mm}$ between the two groups, with and without ankle edema. Are expressed: the mean, $25^{\text {th }}$ and $75^{\text {th }}$ percentiles (blocks) and $10^{\text {th }}$ and $90^{\text {th }}$ percentiles (vertical bars). 


\section{References}

1. Cornu-Thénard A, Scuderi A, Ramelet A-A, et al. UIP 2011 C 3 consensus. Int Angiol 2012;31:4-9.

2. Criqui MH, Janosmos M, Fronek A, et al. Chronic venous diseases in an ethnically diverse population. The San Diego Population Study. Am J Epidemiol 2003;158:448-56.

3. Jawien A, Grezla T, Ochwat A. Prevalence of chronic venous insufficiency in men and women in Poland: multicentre crosssectional study in 40 095 patients. Phlebology 2003;18:11022.
4. Rabe E, Pannier-Fischer F, Bromen K, et al. Bonner Venenstudie des dutsche Gesellshaft für Phlebologie-epidemiologische Untersuchung zur Frage der Häufigkeit und Ausprägung von chronischen Venenkrankheiten in der städtischen und ländlichen. Phlebologie 2003;32:1-14.

5. Rabe E, Pannier F. Clinical, aetiological and anatomical classification (CEAP): gold standard and limits. Phlebology 2012;27:114-8.

6. Sinabulya H, Holmberg A, Blomgren L. Interobserver variability in the clinical assessment of the clinical severity of superficial venous insufficiency. Phlebology 2015;30:61-5.
7. Caggiati A. Ultrasonography of skin changes in legs with chronic venous disease. Eur J Vasc Endovasc Surg 2016;52:534-42.

8. Rastel D, Allaert FA. Early morning edema in varicose vein patients without trophic changes. VASA 2016;45:491-5.

9. Gniadecka M. Localization of dermal edema in lipodermatosclerosis, lymphedema, and cardiac Insufficiency. High-frequency ultrasound examination of intradermal echogenicity. J Am Acad Dermatol 1996;35:37-41. 